\title{
Zoogeography of the ostracod genus Nannocandona (Podocopa) with description of two new species from Europe and East Asia
}

\author{
Ivana Karanovic $^{1 *}$, Dmitry A. Sidorov ${ }^{2}$ and Pierre Marmonier ${ }^{3}$ \\ 1 Department of Life Science, Hanyang University, Seoul 133-791, Korea and Institute of Marine and Antarctic Studies, University of \\ Tasmania, Hobart, Tasmania 7001, Australia \\ 2 Institute of Biology and Soil Science FEB RAS, Vladivostok 690022, Russia \\ 3 Université Lyon 1, CNRS, UMR 5023 - LEHNA, Laboratoire d'Ecologie des Hydrosystèmes Naturels et Anthropisés, Bât. Forel, \\ 69622 Villeurbanne Cedex, France
}

Received 13 June 2015; Accepted 28 September 2015

\begin{abstract}
Candoninae is by far the most diverse ostracod group in subterranean habitats, with many genera which today have no surface water representatives. This subfamily is also peculiar because species tend to have restricted distributions regardless of habitat type, and, unlike other non-marine ostracod lineages, extremely rarely reproduce parthenogenetically. Nannocandona faba Ekman, 1914 is an exception, being originally described from Sweden, but then reported throughout the Holarctic. We study morphological variability of this species here, both based on old museum specimens and on freshly collected material. We propose that the name should only be restricted to the Swedish population, and we describe two new subterranean species: Nannocandona danielopoli n. sp. from Austria, and Nannocandona schornikovi n. sp. from South Korea and the Russian Far East. These descriptions allow us to evaluate records of $N$. faba in other parts of the Holarctic. A new map of the genus distribution is proposed, as well as a key to species identification. Parthenogenetic reproduction of Candoninae and their general ecology is also discussed.
\end{abstract}

Key words: Ostracoda / Candoninae / taxonomy / subterranean waters / parthenogenesis

\section{Introduction}

The genus Nannocandona Ekman, 1914 was established to accommodate a single species, N. faba Ekman, 1914 described from a wetland, or a sort of wet soil (German "Sumpfwiese") near Ostra Lake in Sweden. This small ostracod (around $0.5 \mathrm{~mm}$ long) was subsequently reported from the entire Holarctic, both as a living form (soft parts and shell) and as a Quaternary fossil (see Meisch, 2000). Contrary to its type locality, N. faba is elsewhere collected from interstitial waters from Luntz in Austria (Marmonier and Danielopol, 1988), South Platter River in Colorado (Marmonier and Ward, 1990), and Russian Far East (Schornikov, 2004, 2008), as well as a subspecies N. faba balcanica Sywula, 1967 from Vitosa Mountain in Bulgaria (Sywula, 1967). Nannocandona faba fossils have been reported from North and Central Europe (Absolon, 1973; Diebel and Pietrzeniuk, 1975, 1977, 1984), all from the Pleistocene and Holocene sediments. In the fossil record, the species is associated with spring sediments and it is considered a cold climate indicator (Krstic, 1993), but it

\footnotetext{
*Corresponding author: ivana@hanyang.ac. kr
}

was also recorded from swamp sediments (although these could have been spring fed swamps) from the Late Holocene (see Absolon, 1973). According to Marmonier and Danielopol (1988) interstitial habitats, at least in Western and Central Europe, represent an optimal ecological niche and the species has some morphological characteristics, such as small size and elongated terminal claws on the second antennae, which supposedly represent selective adaptations to this environment or accumulation of neutral mutations. Besides N. faba, the genus has only one more species, Nannocandona stygia described from subterranean waters of Poland (Sywula, 1976).

Unlike most other subterranean Candoninae, N. faba has an exceptionally wide area of distribution. Its presence in North America could be explained by either Tertiary colonization via land bridges or by a more recent, Quaternary colonization, which involved dispersal of living animals or their eggs by birds or wind (see Marmonier and Ward, 1990). The latter is supported by the fact that the North American and European populations display a very similar morphology and that $N$. faba reproduces parthenogenetically, which allows for a population establishment by a single female (Martens, 1998). 
Table 1. Ecological characteristics and geographic coordinates of the localities from where Nannocandona species were collected so far.

\begin{tabular}{|c|c|c|c|c|c|c|}
\hline Species name & Type & Coordinates & $\begin{array}{l}\text { Water T } \\
\left({ }^{\circ} \mathrm{C}\right)\end{array}$ & $\begin{array}{c}\text { Elevation } \\
\text { (m asl) }\end{array}$ & Climate type & References \\
\hline N. faba & Interstitial & $39.3617 \mathrm{~N}, 106.06 \mathrm{E}$ & $6-18.5$ & $1670-451$ & Alpine & $\begin{array}{c}\text { Marmonier and Ward (1990); } \\
\text { Ward and Voelz, (1994) }\end{array}$ \\
\hline N. danielopoli & Interstitial & $47.8529 \mathrm{~N}, 15.0647 \mathrm{E}$ & $\begin{array}{c}2-12 \\
\text { (mean 6.6) }\end{array}$ & 600 & Alpine & $\begin{array}{l}\text { Marmonier and Danielopol } \\
\text { (1988); present paper }\end{array}$ \\
\hline N. schornikovi & Interstitial & $37.83475 \mathrm{~N}, 128.647315 \mathrm{E}$ & 12 & 270 & Humid continental & Present paper \\
\hline
\end{tabular}

On the other hand, this model is disputed by the fact that N. faba lives in interstitial waters. Dispersal of eggs or adults by either birds or wind would be difficult from this habitat. Also, for eggs to be carried long distances they need to be drought resistant, and it seems that no Candoninae produces such eggs, although torpidity has been recorded (see Horne, 1993; Smith and Delorme, 2009).

Parthenogenetic reproduction is common in freshwater ostracods. However, in the subfamily Candoninae it is a rare incident, and so far only a handful of over 500 species (see Martens and Savatenalinton, 2011; Karanovic, 2012) have been reported to reproduce exclusively in this way or have very rare bisexual populations. According to Martens (1998) and Martens et al. (1998) a low intraspecific genetic and morphological variability, along with clear interspecific gaps, are norms in ancient asexual lineages (such as Darwinulidae), and should facilitate identification of discrete species. On the other hand, species with mixed reproduction, and especially those that are asexual spin-offs from species with sexual roots, may pose taxonomical problems because there is often not enough morphological or molecular differences to allow for congeneric linages identification, and Martens (1998) and Martens et al. (1998) propose a theoretical, agamospecies, concept.

In this paper, we assess the records of $N$. faba from the morphological point of view and propose that the name should be restricted only to the Swedish population, while other interstitial populations from Europe represent a distinct species. We also dispute the finding of $N$. faba in North America and describe another new species recently collected from interstitial waters of East Asia (Russian Far East and South Korea). This overview allows us to present a map of current distribution of Nannocandona in the world and also to propose a taxonomic key for the living species identifications.

\section{Material and methods}

Samples from Korea were collected using the Karaman-Chappuis method (Chappuis, 1942), which consists of digging a funnel-shaped excavation into the sediment down to the groundwater level, allowing water to fill the bottom of the pit, and then collecting that water with a dish and filtering it through a plankton net; and in
Russia with a phreatobiological hand-pump, similar to the Bou-Rouch pump (Bou and Rouch, 1967; Bou, 1974). The Austrian population was sampled using standpipes pushed inside river sediment to passively catch drifting animals (Bretschko, 1983; Marmonier and Danielopol, 1988). The groundwater intake was at a depth of $\sim 30 \mathrm{~cm}$; at site, $200 \mathrm{~L}$ of arenaceous water was pumped, floated and clarified through a hand net with $250-\mu \mathrm{m}$ mesh. Samples were preserved in $99 \%$ ethanol, and ostracods were sorted using a dissecting microscope Olympus SZX12 and Lomo MBS9. Specimens were dissected and mounted on microscope slides in CMC-10 Mounting Media (Masters Company, Inc.), and dissected appendages were then covered with a coverslip. All drawings were prepared using a drawing tube attached to a Leica DMLS brightfield compound microscope with N-PLAN achromatic objectives. Specimens that were not drawn were examined in a mixture of equal parts of distilled water and glycerol and, after examination, were again preserved in $70 \%$ ethanol. SEM images were taken with the Hitachi S-4700 scanning electron microscope at Eulji University in Seoul. Material is deposited at the National Institute of Biological Research (NIBR) in Seoul (type material of the new East Asian species), the Zoological Collection of the Museum of Evolution, Uppsala University (UPSZTY) (type material of the new European species), and in Institute of Biology and Soil Science (IBSS) (some additional materials of the new East Asian species). Table 1 summarizes ecological characteristics and coordinates of both newly described species, as well as some of the previous records. Data for $N$. faba are taken from its original description (Ekman, 1914) and do not include later fossil findings; data for one unnamed Nannocandona species from North America are not included because there is insufficient information in Smith and Delorme (2009). Data for the European new species do not include potential conspecific finding from Poland (see Fig. 8 and discussion); while data for the Asian new species include only present finding of the species from Korea and Russian Far East.

The terminology for the A1, Md, Mxl, L5 and L6 follows Broodbakker and Danielopol (1982), and for the L7 Meisch (1996). Here, the view of Meisch (2007) regarding the terminology and homology of the most posterior appendage on the ostracod body ("furca") is accepted. Setal classification system follows Garm (2004). 
Kempf (1980a, 1980b, 1980c, 1980d, 1991, 1997a, 1997b, 1997c, 1997d) indexes and bibliographies of the freshwater ostracods have been extensively used in checking the availability of names and publications.

Abbreviations used in text and figure captions: A1, antennula; A2, antenna; UR, uropodal ramus; $\mathrm{H}$, height; L, length; LV, left valve; Md, mandible; Mx, maxillula; $\mathrm{RV}$, right valve; L5, L6, L7, first, second and third thoracopods; W, width.

\section{Results}

Class Ostracoda Latreille, 1802

Order Podocopida Sars, 1866

Family Candonidae Kaufmann, 1900

Subfamily Candoninae Kaufmann, 1900

Genus Nannocandona Ekman, 1914

Type species: Nannocandona faba Ekman, 1914

Other species and sub-species: N. faba balcanica Sywula, 1967, N. danielopoli n. sp., N. schornikovi n. sp., N. stygia Sywula, 1976

Revised diagnosis: Shell usually smooth and only covered with sparse sensilla. Carapace rectangular in lateral view and narrow in dorsal view. Calcified inner lamella very narrow, marginal pore canals short and straight. A1 with several segments fused, resulting in 5- or 6-free segments. A2 4-segmented, with conspicuously looking exopodite consisting of one long and one short seta. Md-palp 4-segmented with terminal segment armed with two strong, distally broadened claws. L5 with one a-seta. L6 5-segmented and basal segment without any seta. L7 4-segmented, basal segment with d1- and dp-seta, only e-seta present on penultimate segment, terminal segment with two long and one short seta. UR with short, and stout ramus and two equally long distal claws, both anterior and posterior setae present. Female genital field rounded and without any projections. Male characteristics unknown.

\section{Nannocandona faba Ekman, 1914}

Synonymy

Nannocandona faba n. sp. - Ekman (1914): p. 20, Figs. 49-56

Nannocandona faba Ekman - Alm (1915): p. 140, Fig. 86

[non] Nannocandona faba Ekman - Marmonier and Ward (1990): p. 232, Figs. 5C, D; 6E-G

\section{Remarks}

Personal communication with Dr Erica Mejlon, the Curator of the Zoological Collection of the Museum of Evolution, Uppsala University, revealed that the collection contains an entry "Nannocandona faba", labeled as "type", collection number UPSZTY 2319. We have received this material on loan, and it contains one plastic vial with one glass vial inside and a total of four specimens. Only the plastic vial carried the label Nannocandona faba, type, while the inside label reads: "Candona gibbera
Ekman, Typex, Västmanland, bog near V. Skälsjön, Skinnskatteberg sn". We have dissected one of the four females (currently with the collection number: UPSZTY 162736) and found out that the species is not Nannocandona faba, but some other Candoninae species. Since the name "Candona gibbera" was never published, neither by Ekman, nor by anyone else, we think that this may be a species Ekman was working on at the time, giving it a provisional name. Therefore, we conclude that the type material of $N$. faba does not exist anymore in the Zoological Collection of the Museum of Evolution, Uppsala University, and very likely nowhere else.

\section{Nannocandona danielopoli $\mathrm{n}$. sp.}

Figures 1(A); 2(A) and (B); 3(C)-(E); 4(E)-(G); 5(C) and (D); 6(B) and (G); 7(C) and (D)

\section{Synonymy}

Nannocandona faba Ekman - Marmonier and Danielopol (1988): p. 37, Figs. 1-3; Meisch (2000): p. 61, Fig. 19

Holotype: One female dissected on one slide (UPSZTY 162738)

Paratypes: Three females on SEM stubs (UPSZTY 162737)

Type locality: Austria, Lunz am See, no. 7061, Interstitial habitat of the Seebach, 47.8529 N, 15.0647 E, 1985, collector G. Bretschko.

Etymology: The species is named in honor of Dr Dan L. Danielopol (Institute of Earth Science, Karl-FranzensUniversität, Graz), in honour to his outstanding contribution to our knowledge of the biodiversity and evolution of subterranean ostracods.

\section{Description}

Female: Shell rectangular in lateral view (Fig. 1(A)) with a dorsal saddle-like depression, more expressed in the LV. LV overpassing RV dorsally in lateral view. Dorsal margin straight along its entire length (except for a saddlelike depression), then sloping down toward anterior and posterior margin. Dorsal margin on LV better developed than on RV, upper third of anterior and posterior margins straight and in oblique position. Rest of posterior and anterior margins rounded, but posterior margin narrower and more steeply inclined than anterior one (Fig. 4(E) and (F)). Ventral margin almost straight, or on the RV slightly inwardly bent, while variable on the LV. Calcified inner lamella narrow, and slightly narrower posteriorly than anteriorly. Marginal pore canals very short. In dorsal view (Fig. 4(G)) LV overpasses RV considerably on both anterior and posterior end. Lateral margins evenly curved. Shell surface covered with long hair-like setae (Fig. 2(A)) exiting from rimmed pores (Fig. 2(B)). Each surface seta with a bulbous, sculptured root. $\mathrm{L}$ varies from 0.38 to $0.42 \mathrm{~mm}$, greatest $\mathrm{H}$ equalling $57 \%$ of $\mathrm{L}$; greatest $\mathrm{W}$ varying from 49 to $50 \%$ of L. No surface ornamentation.

A1 (Fig. 5(C)): With five podomeres. First podomere with one pappose seta antero-proximally and one serrulate 


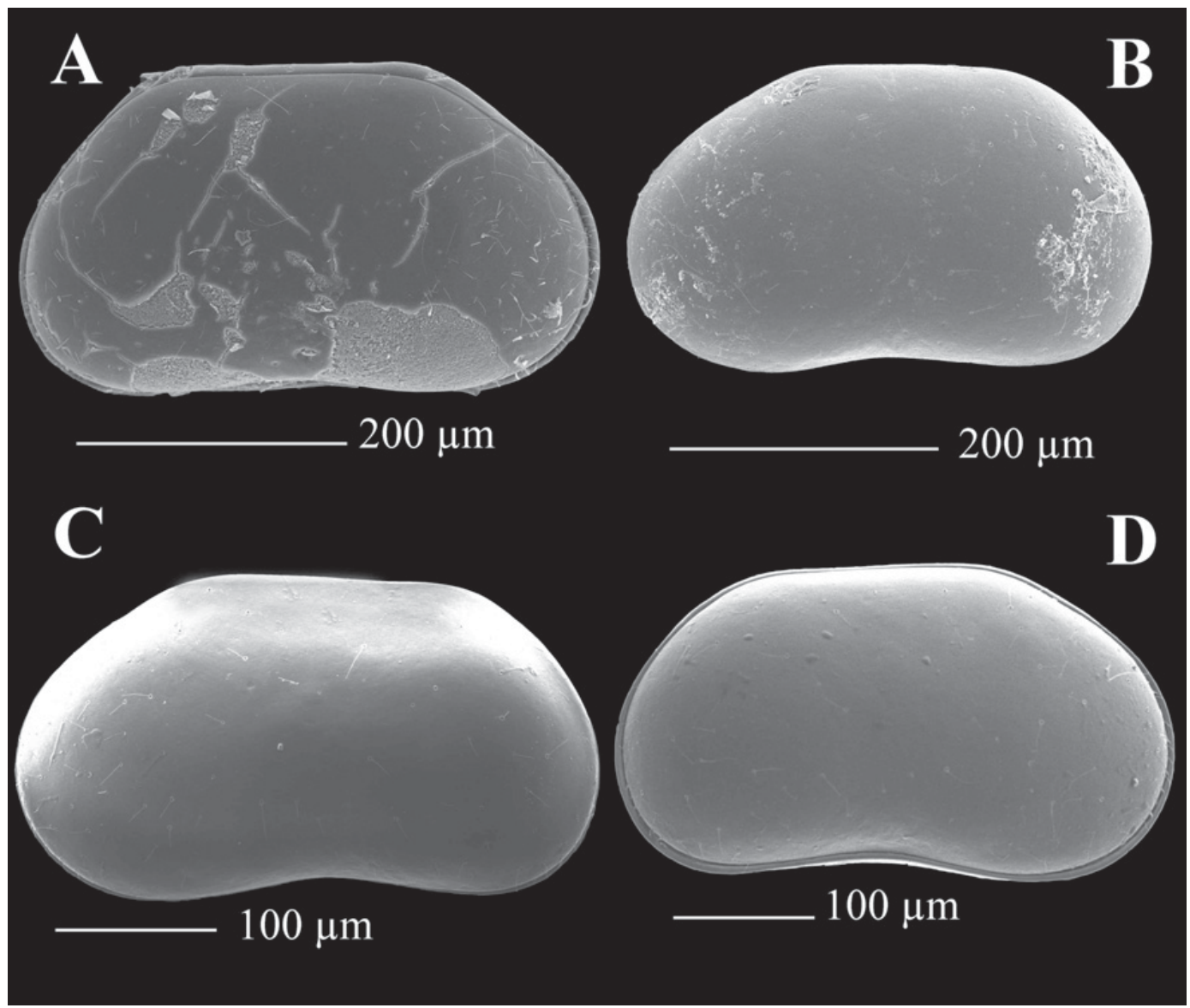

Fig. 1. SEM photographs - A: N. danielopoli n. sp., paratype female; B-D: N. schornikovi n. sp, paratype females; B: Russia; C, D: South Korea; A: entire shell, lateral view from the right side; B, C: LV, external view; D: entire shell, lateral view from the right side.

seta postero-distally; postero-distal seta long and reaching distal end of terminal segment. No Wouters or Rome organs present. Second with one apparently smooth seta antero-distally, almost reaching tip of terminal segment. Following podomere with one seta each on antero- and postero-distally; both setae smooth, equally long, and exceeding distal end of terminal segment. Penultimate podomere with two long antero-distal setae. Terminal podomere with one posterior shorter seta, two long setae and aesthetasc "ya" which is almost 3.5 times longer than terminal segment. $L$ ratios between segments 2 and 5 equalling $2: 1.7: 1: 1.3$

A2 (Figs. 3(C) and 5(D)): Four-segmented. Exopod represented with one plate with one short and stout seta and one long seta, reaching mid L of penultimate segment. Protopod with one potero-distal, long seta. First endopodal segment with aesthetasc " $Y$ ", almost as long as this segment; same segment with two serrulate setae posterodistally: one being half as long as the other. Penultimate segment with one antero-medial serrulate seta and two " $\mathrm{t}$ " setae situated postero-medially; aesthetasc "y1" situated slightly above "t" setae. Only two " $z$ " setae present, " $z 1$ " transformed into a claw and being two times longer than terminal segment; "z2" seta-like and only slightly exceeding terminal segment. All " $G$ " claws on penultimate segment long and slender and almost two times longer than the first endopodal segment. Terminal segment very short, carrying long "GM" claw (almost as long as other "G" claws) and less than half as long "Gm" claw; aesthetasc "y3" only slightly shorter than "Gm" claw. $\mathrm{L}$ ratio between first and second endopodal segment equalling 1.1:1. Both segments elongated and $\mathrm{L}: \mathrm{W}$ ratio of first endopodal segment equalling $2: 1$; while same ratio on penultimate segment equalling 2.5:1.

Md (Fig. 6(D)). Palp 4-segmented. First segment with four setae: two long (one probably representing " $S$ " seta), plumose setae, one very short smooth seta (" $\alpha$ ") and one stout and short plumose seta (probably reduced "S" seta). Second segment with one extero-distal seta and a total of five $(3+2)$ setae internally to medially. Penultimate segment with two serrulate extero-distal setae, one medial smooth seta (" $\gamma$ ") and two intero-distal setae. Terminal segment with two strong claws, of which the medial one fused with the segment; two slightly shorter and very slender setae accompanying the medial claw. Both claws with tufts of setulae at tips.

Mxl. Palp 2-segmented. First segment with four setae: three more external onles slender and long, medial one shorter. Terminal segment rectangular carrying two claws and three setae.

L5 (Fig. 6(B)). Only one "a" seta present, no vibratory plate observed. Both "b" and "d" setae present. 


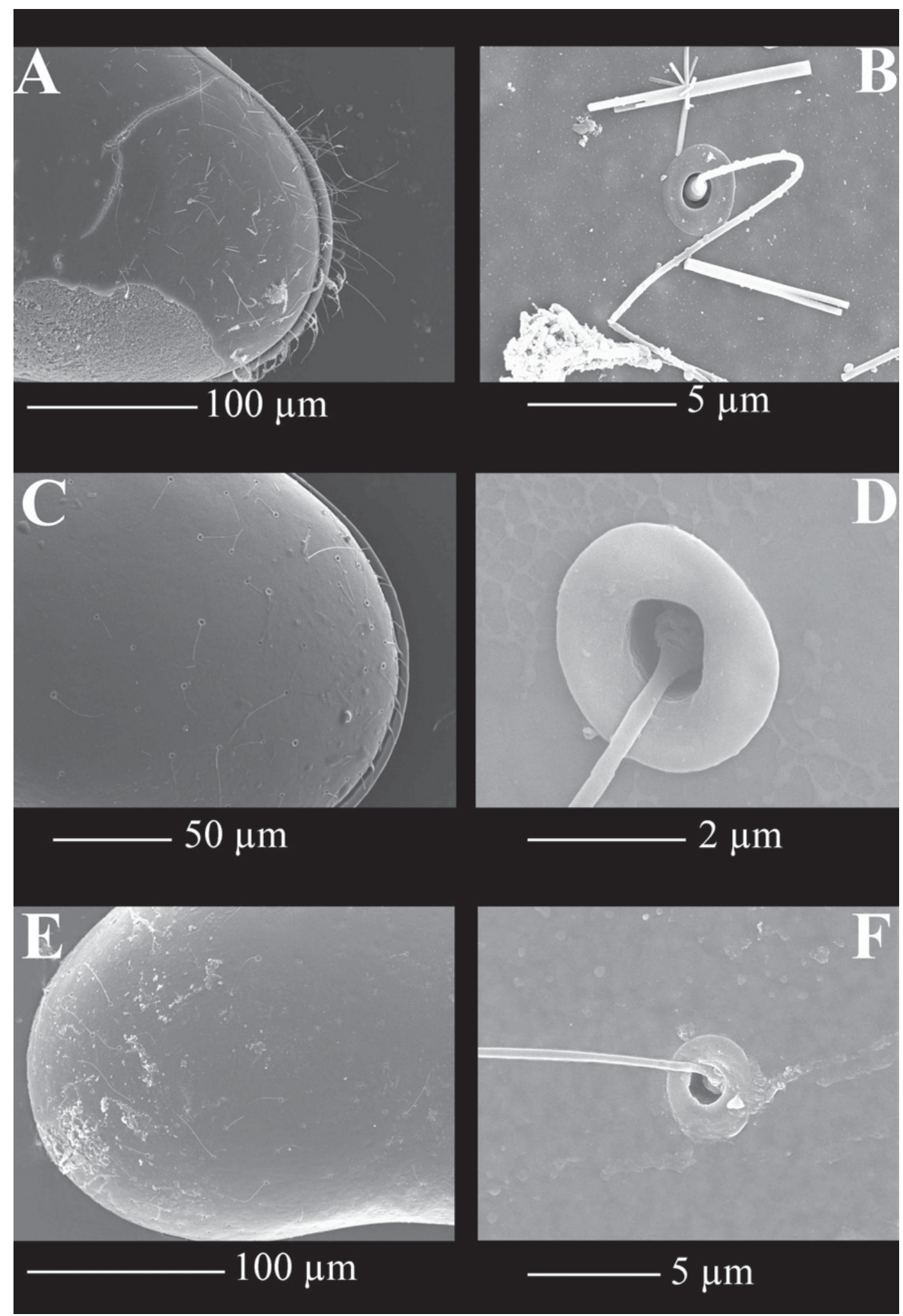

Fig. 2. SEM photographs. A, B: N. danielopoli n. sp., paratype female; B-F: N. schornikovi n. sp, paratype females; C, D: South Korea; E, F: Russia; A: entire shell, anterior part, detail; B: surface sensory seta; C: entire shell, anterior part detail; D: surface sensory seta; E: LV, detail of the anterior end; F: surface sensory seta.

L6 (Fig. 6(G)): Five-segmented. Basal segment without any seta. First endopodal segment with one antero-distal seta reaching only $1 / 3$ of the following segment. Second segment with one antero-distal seta reaching distal margin of penultimate segment. Penultimate segment with only one seta observed. 


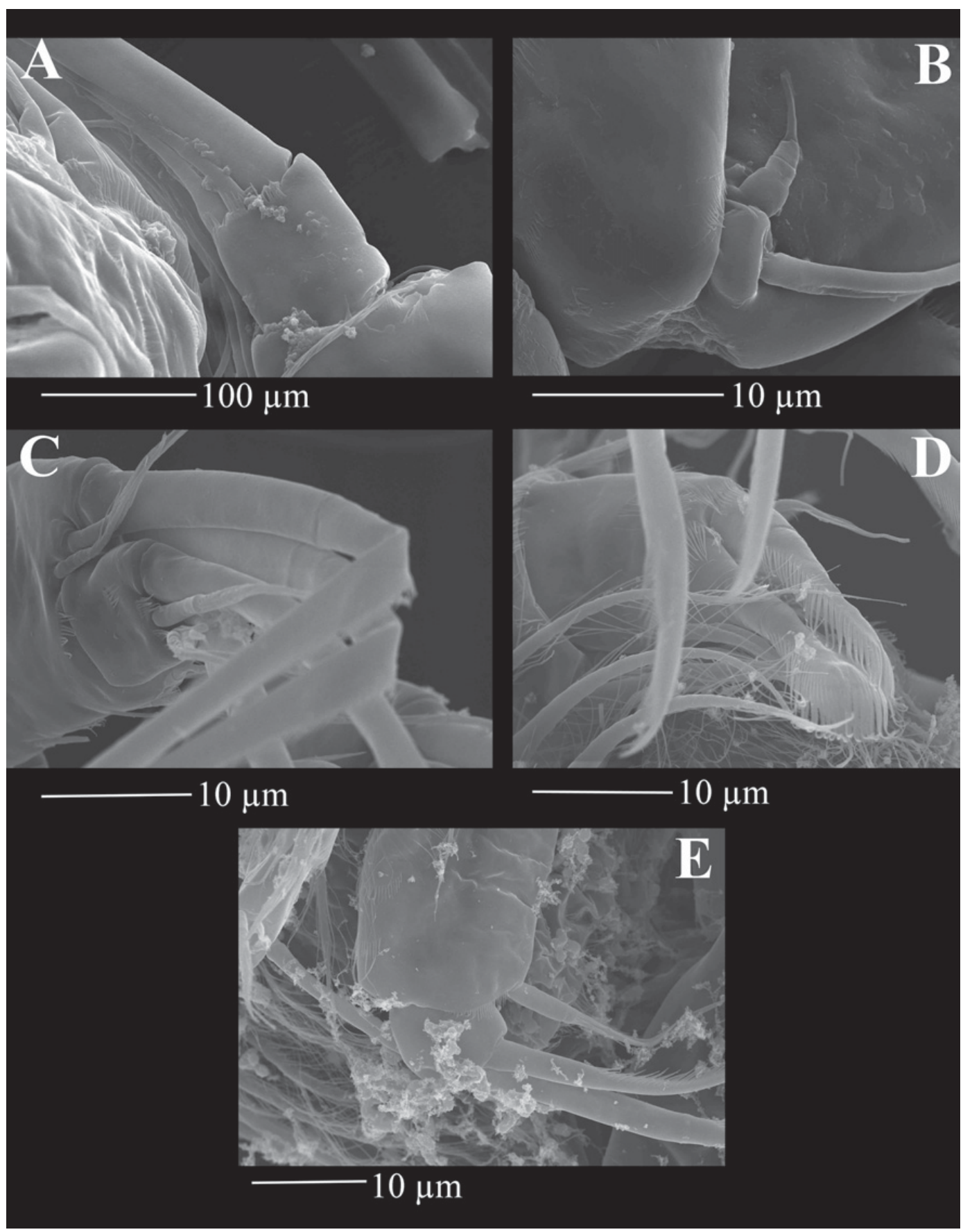

Fig. 3. SEM photographs. A, B: N. schornikovi n. sp., paratype female; C-E: N. danielopoli n. sp., paratype female; A: detail of the terminal segment A2; B: exopod A2; C: detail of the terminal segment of A2; D: distal claws on the Md palp; E: distal end of L6.

Terminal segment carrying two short setae and long, slender claw. Terminal claw not serrated and 1.5 times longer than combined $\mathrm{L}$ of second and third endopodal segments. Second and third endopodal segments almost equal in size.

L7 (Figs. 3(E) and 7(C)): Four-segmented. Basal segment with "dp" and "d1" seta only. Setae "e" and "f" missing. Penultimate segment not divided and distally with "g" seta, more than two times longer than terminal segment. Terminal segment with two long ("h2" and "h3" seta) and one less than half as long seta ("h1").

UR (Fig. 7(D)): With both claws and both setae present. Terminal claws equally long and representing only $70 \%$ of anterior margin of the ramus. Genital field rounded. 


\section{Remarks}

Nannocandona danielopoli was previously considered to be conspecific with $N$. faba. The major differences between the two species are as follows:

1. Ventral margin is almost straight in the new species and strongly concave in $N$. faba;

2. Posterior margin in lateral view seems to be more rounded in N. faba than in the new species;

3. In dorsal view, there is a more prominent $\mathrm{LV} / \mathrm{RV}$ overlap both anteriorly and posteriorly in the new species than in N. faba;

4. A1 is clearly 4-segmented in N.faba and 5-segmented in $N$. danielopoli;

5. Postero-distal seta on the penultimate segment of A1 is missing in N. faba;

6. Postero-distal setae on the second endopodal segment of A2 in the new species are much shorter in N. faba;

7. Terminal claws on the Md palp seem to be stronger (i.e., wider) in $N$. faba than in $N$. danielopoli;

8. Distal seta on the first endopodal segment of L5 seems to be longer in N. faba;

9. Seta "e" on L7 present in N. faba, while "dp" seta absent.

With the exception of differences 1-4 and 7, all the other ones can be interpreted as a result of wrong observations. For example, the lack of some setae in $N$. faba, or some setae being shorter, may be explained by the fact that the species is very small (according to Ekman (1914) length is $0.41-0.43 \mathrm{~mm}$ ) resulting in many obscure details. In addition, we believe that the absence of "dp" seta and the presence of "e" seta on L7 in N. faba is a wrong interpretation of the "dp" seta itself. Namely, this seta can be positioned in such a way that it goes under the segments and protrudes right at the place where the "e" seta should origin.

The number of segments of A1 can also be wrongly interpreted, and sometimes the division between segments cannot be clearly observed. In this case, however, there should be a considerable difference in $\mathrm{L}$ of segments when they are compared between two species. Nevertheless, in $N$. danielopoli the last two segments of its 5-segmented A1 are much longer than either the terminal or the penultimate segments of the 4-segmented A1 in N. faba. Beside the segments number on the A1, the differences in the shell outline both in lateral and dorsal views, as well as the peculiarly looking strong claws on the Md palp in $N$. faba are strong evidence to support description of a new species.

\section{Nannocandona schornikovi $\mathrm{n}$. sp.}

Figures 1(B) $-(\mathrm{D}) ; 2(\mathrm{C})-(\mathrm{F}) ; 3(\mathrm{~A})$ and $(\mathrm{B}) ; 4(\mathrm{~A})-(\mathrm{D})$, (H)-(K); 5(A), (B), (E), (F); 6(A), (C)-(F); 7(A), (B), (E), (F) Synonymy

Nannocandona faba Ekman - Schornikov (2004): p. 460, Fig. 7; Schornikov (2008): p. 86; Sidorov and Semenchenko (2012): p. 233.
Holotype: One female dissected on one slide (NIBRIV 0000325506)

Paratypes: Two females dissected on two slides (NIBR IV0000325507, NIBR IV0000325508), three female on SEM stub (UPSZTY 162737)

Type locality: Hyporheic zone, small creek, Odaesan National Park, South Korea, 37.83475N, 128.647315E, 09/10/2012, coll. T. Karanovic.

Other material: One female dissected on one slide (IBSS 4KEDR), one female on SEM stub (UPSZTY 162737), from hyporheic zone, depth 20-30 cm, Phillipovka River, Khasansky territory, Primorsky Krai, Russia, 43.23245N 131.548617E, 05/10/2010, coll. D. Sidorov and K. Semenchenko.

Etymology: The species is named in honour of Dr Eugen Schornikov (A. V. Zhirmunsky Institute of Marine Biology, Vladivostok, Russia), in honour to his outstanding contribution to our knowledge of the biodiversity and evolution of ostracods.

\section{Description}

Female: Shell rectangular in lateral view (Fig. 1(B)-(D)) with a dorsal saddle-like depression, but less developed than in the previous species. LV overpassing RV dorsally in lateral view (Figs. 1(D), 4(C) and $(\mathrm{H})$ ). Dorsal margin straight along its entire length, than slopping down towards anterior end and rounded towards posterior end. Posterior and anterior margins rounded, but posterior margin more rounded than the anterior one (Fig. 4(A)-(C); (H), (I) and (K)). Ventral margin slightly concave. Calcified inner lamella narrow and slightly narrower posteriorly than anteriorly. Marginal pore canals very short. In dorsal view (Fig. 4(D) and (J)), LV overpasses RV considerably on both anterior and posterior end. Lateral margins evenly curved. Shell surface covered with long hair-like setae (Fig. 2(C)-(F)) which exiting rimmed pores. $\mathrm{L}$ varies from 0.35 to $0.4 \mathrm{~mm}$, greatest $\mathrm{H}$ equalling $58 \%$ of $\mathrm{L}$; greatest $\mathrm{W}$ around $50 \%$ of L. No surface ornamentation.

A1 (Fig. 5(A) and (B)): With five podomeres and with unclear separation between the last two podomeres. First podomere with one pappose seta antero-proximally and one serrulate seta postero-distally; postero-distal seta long and reaching distal end of terminal segment. Second with one apparently smooth seta antero-distally, almost reaching tip of terminal segment. Following podomere with one seta each on antero- and postero-distally; both setae smooth, posterior slightly shorter than the anterior. Penultimate podomere with two long antero-distal setae. Terminal podomere with one posterior shorter seta, two long setae and aesthetasc "ya" which almost five times longer than terminal segment. L ratios between segments 2 and 5 equalling 1.4:1.5:1:1.

A2 (Fig. 5(E) and (F)): Four-segmented. Exopod represented with one plate with one short and stout seta and one long seta, reaching mid $\mathrm{L}$ of penultimate segment. Protopod with one postero-distal, long seta. 


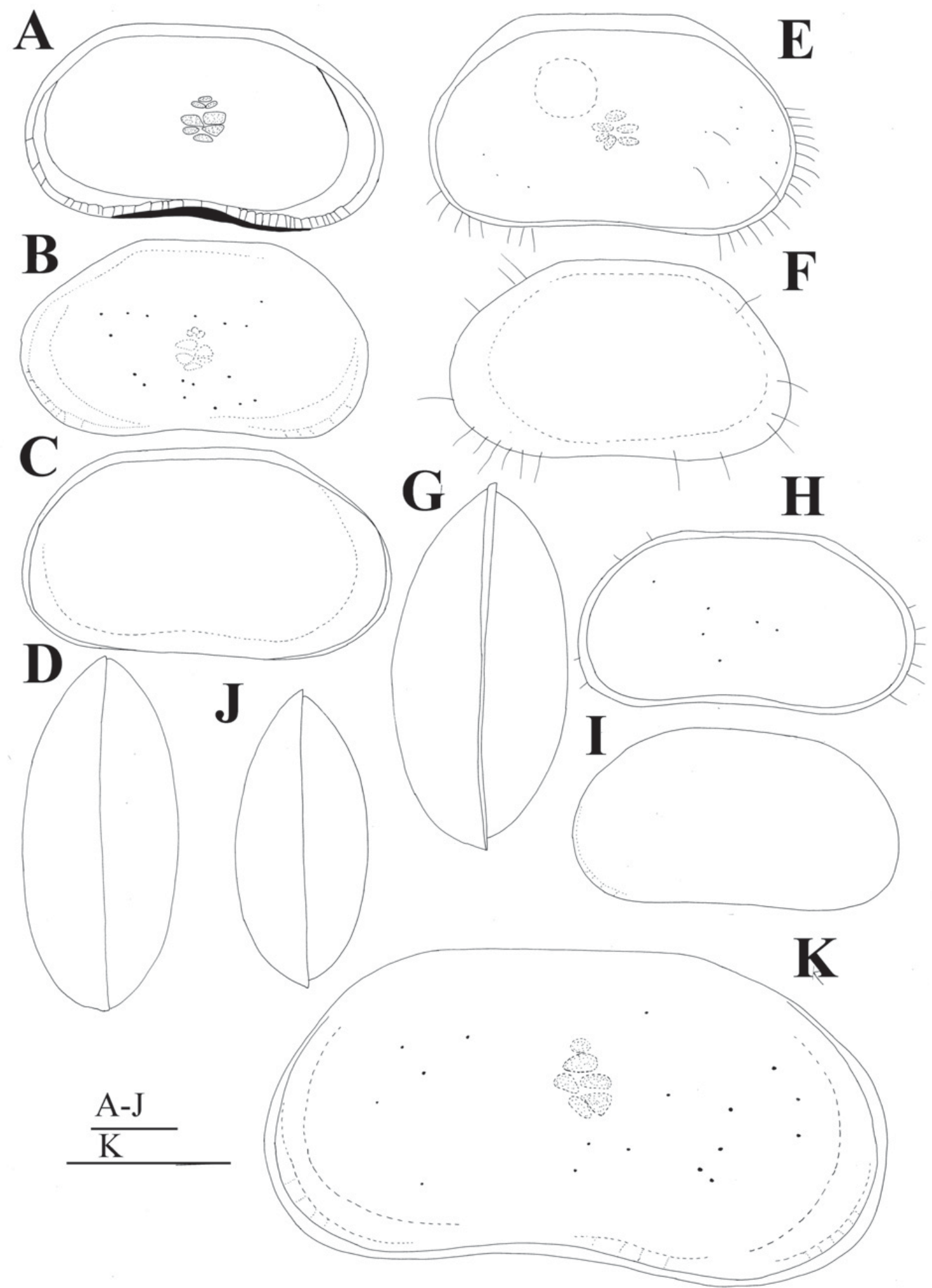

Fig. 4. Line drawings of the shells. A-D, H-K: N. schornikovi n. sp., A-D:, paratype females, Russia; H-J: paratype females, South Korea: K: holotype female, South Korea; E-G: N. danielopoli n. sp.; E: holotype female; F, G: paratype females; A: LV, lateral view from the inside; B: LV, lateral view from the outside; C: whole shell, lateral view from the right side; D: dorsal view of the shell; E: whole shell, lateral view from the right side; F: LV, lateral view from the left side; G: dorsal view, whole shell; H: whole shell, lateral view from the right side; I: LV, lateral view from the outside; J: dorsal view, whole shell; K: whole shell, lateral view from the right side. Scales $=0.1 \mathrm{~mm}$. 


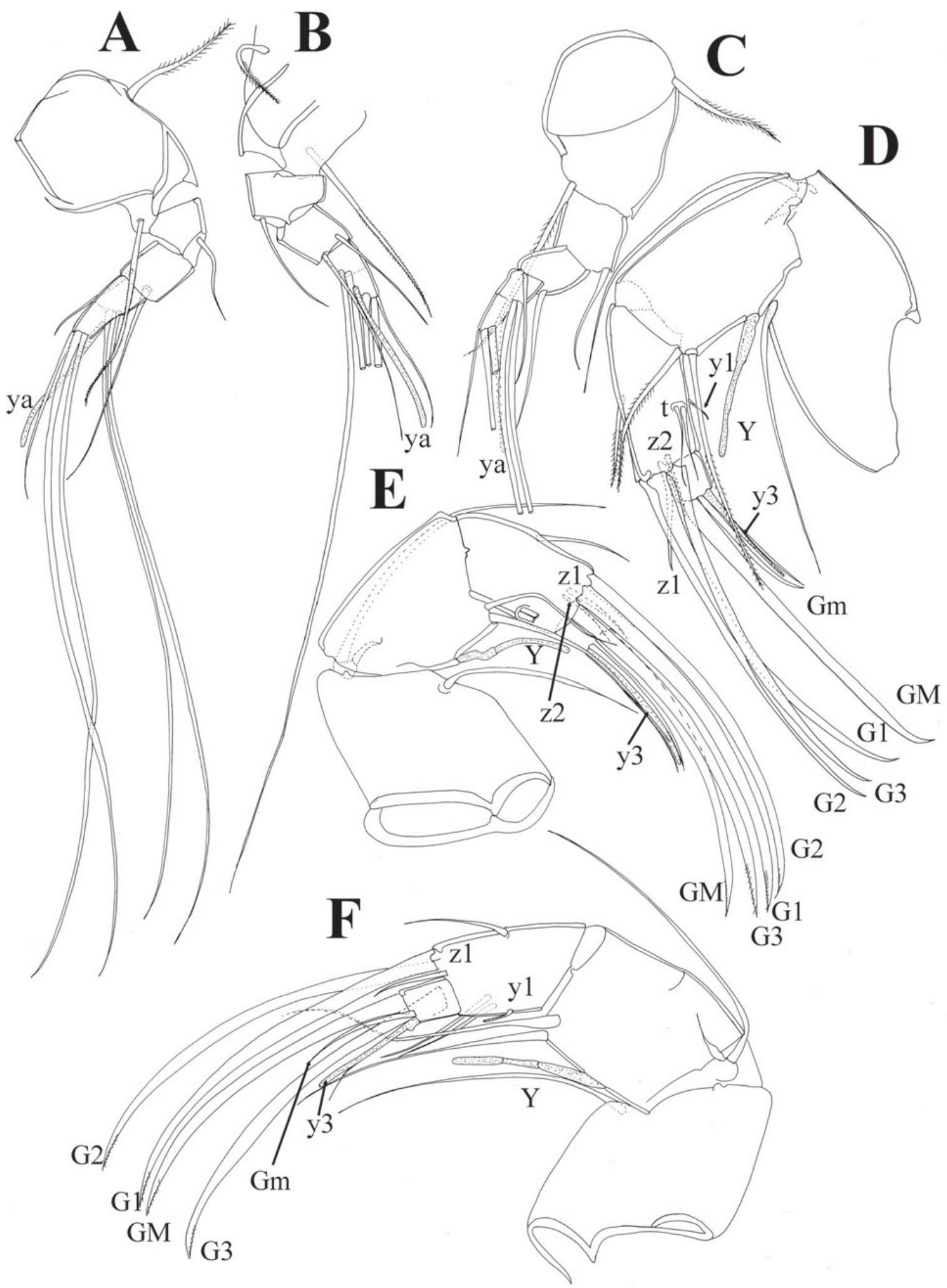

Fig. 5. Line drawings. A, B, E, F: N. schornikovi n. sp.; A, E: paratype female, Russia; B, E: holotype female, South Korea; C, G: N. danielopoli n. sp, holotype female; A-C: A1; D-F: A2. Scale $=0.1 \mathrm{~mm}$.

First endopodal segment with aesthetasc "Y", almost as long as this segment; same segment with two setae postero-distally: one being slightly shorter than the other. Penultimate segment with one antero-medial serrulate seta and two "t" setae situated postero-medially; aesthetasc "yl" situated slightly above " $t$ " setae. Only 
two " $\mathrm{z}$ " setae present, " $\mathrm{zl}$ " transformed into a weak claw and being 1.5 times longer than terminal segment; "z2" seta-like and only slightly exceeding terminal segment. All "G" claws on penultimate segment long and slender and almost two times longer than the first endopodal segment. Terminal segment very short, carrying long "GM" claw (almost as long as other "G" claws) and less than half as long "Gm" claw. L ratio between first and second endopodal segment equalling 1.3:1. Both segments elongated and L:W ratio of first endopodal segment equalling 1.2:1; while same ratio on penultimate segment equalling 1.5:1.

Md (Fig. 6(D)): Same as in the previous species.

Mxl (Fig. 6(C)): Same as in the previous species.

L5(Fig. 6(A)): Same as in the previous species.

L6 (Fig. 6(E) and (F)): Five-segmented. Basal segment without any seta. First endopodal segment with one antero-distal seta reaching margin of the following segment. Second segment with one antero-distal seta not reaching distal margin of penultimate segment. Penultimate segment with only one seta observed. Terminal segment carrying two short setae and long, slender claw. Terminal claw distally serrated and 1.7 times longer than combined $\mathrm{L}$ of second and third endopodal segments. Second segment considerably shorter than third endopodal segment.

L7 (Fig. 7(A) and (B)): Four-segmented. Basal segment with "dp" and "d1" seta only. Setae "e" and "f" missing. Penultimate segment not divided and distally with "g" seta, more than two times longer than terminal segment. Terminal segment with two long ("h2" and "h3" seta) and one less than half as long seta ("h1").

UR (Fig. 7(E) and (F)): With both claws and both setae present. Terminal claws equally long and as long as the anterior margin of the ramus. Genital field rounded.

\section{Remarks}

The three major differences between $N$. schornikovi on one side and both $N$. danielopoli and $N$. faba on the other are:

1. Second and third segments of A2 are stouter in $N$. schornikovi than in $N$. danielopoli and N. faba;

2. Second and third segments of the L5 have the same $\mathrm{L}$ in N. danielopoli and N. faba, while in N. schornikovi the second one is considerably shorter than the third one;

3. The uropodal ramus is longer than the terminal claws in $N$. danielopoli and N.faba, while it is as long as the claws in $N$. schornikovi, so that the entire structure appears stout in this species.

Additional difference between $N$. schornikovi and $N$. faba is the number of segments on the A1: 5 in the new species and 4 in $N$. faba. The differences between $N$. schornikovi and $N$. danielopoli can also be found in the shell outline in lateral view, because $N$. schornikovi has more rounded posterior margin than $N$. danielopoli in which the margin is rather inclined.

\section{Key to living species of Nannocandona}

1. Surface of the shell ornamented with distinctly developed pits ......................... Nannocandona sp. (from Smith and Delorme, 2009)

- Surface of the shell smooth ................................... 2

2. Terminal segment of the Md palps with two conspicuous strong claws .................................... 3

- Terminal segment of the Md palp with two slender claws ................................. N. stygia Sywula, 1976

3. A1 with four podomeres ....... N. faba Ekman, 1914

- A1 with five podomeres ...................................... 4

4. Posterior and anterior margins of the LV prominently inclined and same valve with markedly developed saddle-like medial part ............ $N$. danielopoli n. sp.

- Posterior and anterior margins of the LV more rounded and same valve with very faint saddle-like medial part 5

5. Anterior margin of UR longer than anterior claw and both first and second segments of A2 elongated with L : W ration being over $1.5 \ldots \ldots \ldots \ldots . . . . . N$. faba (in Marmonier and Ward, 1990)

- Anterior margin of UR same or shorter than anterior claw and both first and second segments of $\mathrm{A} 2$ robust with $\mathrm{L}: \mathrm{W}$ ration being 1.5 or less . N. schornikovi n. sp.

\section{Discussion}

The position of Nannocandona within one of the eight Candoninae tribes is currently unresolved. The tribal division of the subfamily Candoninae proposed by Karanovic (2007) is still not widely accepted, with an exception of the tribes Candonopsini and Terrestricypridini (see, for example, Pinto et al., 2005; Higuti and Martens, 2012, 2014). Nannocandona is traditionally recognized as a member of the most diverse tribe, Candonini (see, for example, Martens, 1992; Martens and Savatenalinton, $2011)$. On the other hand, Karanovic $(2007,2012)$ placed Nannocandona into the tribe Terrestricypridini, which contains a group of genera found in semiterrestrial ecosystems, such as leaf litter and wet mosses in South America (Pinto et al., 2005). One of the morphological reasons for this systematic rearrangement is that all Terrestricypridini have a strong claw on the terminal segment of the cleaning leg (L7), and previous illustrations of Nannocandona faba led Karanovic $(2007,2012)$ to wrongly interpret this character. Nevertheless, a reduced number of segments on the A1, and carapace shape which is inconspicuous, kidney-shaped or rectangular, with very narrow inner calcified lamella, as well as terminal claws on the Md palp (strongly developed), should be reasons enough not to completely discard a close phylogenetic relationship between Nannocandona and 


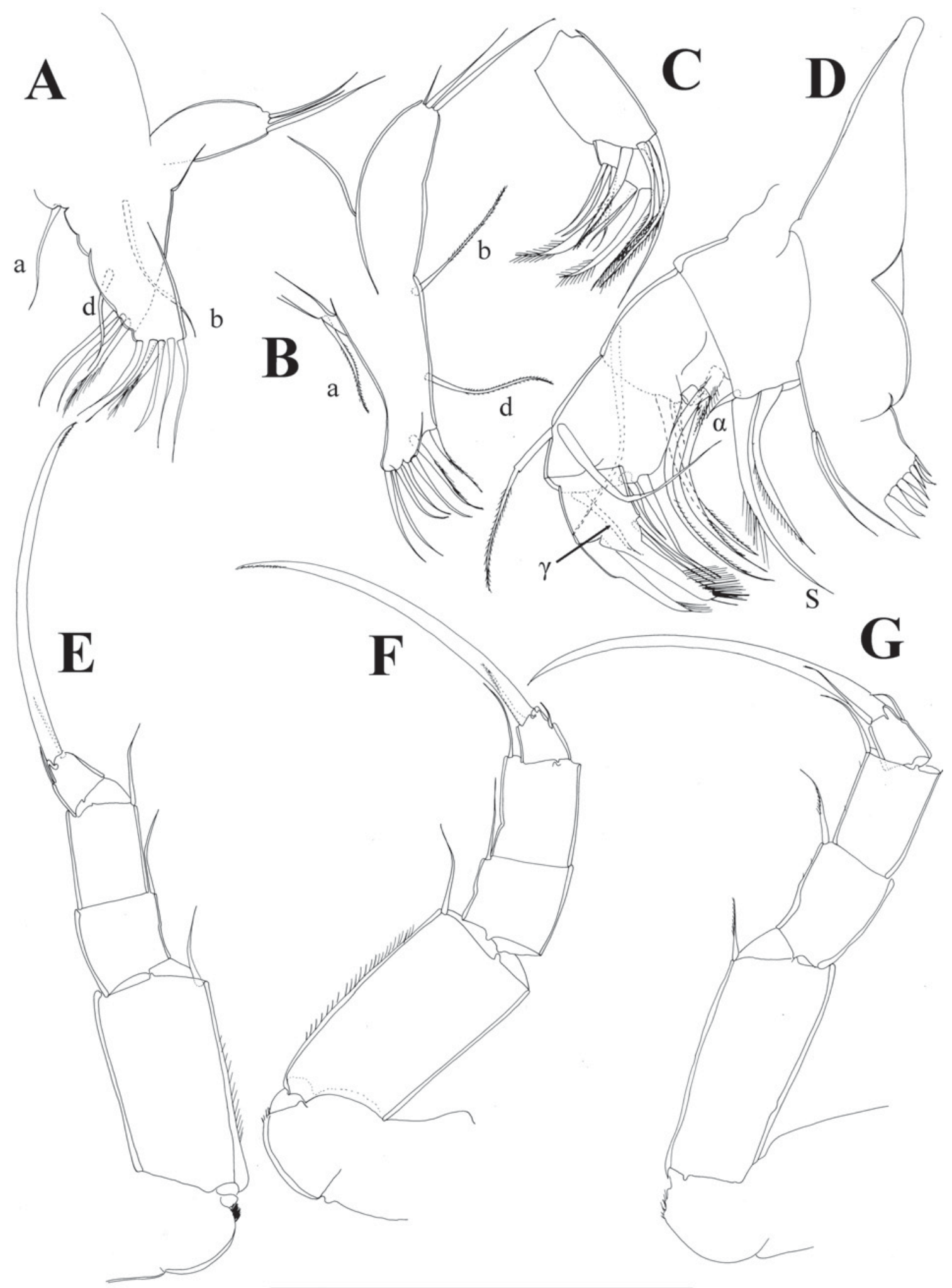

Fig. 6. Line drawings. A, C-F: N. schornikovi n. sp.; A, F: holotype female, South Korea; C-E: paratype female, Russia; B, G: N. danielopoli n. sp. holotype female: A, B, L5; C, Mxl palp; D, Md; E-G, L6. Scale =0.1 mm.

Terrestricypridini. These characters could also be a result of convergent evolution, an adaptation to the ecosystems where water is not abundant and animal navigates through tiny spaces. The latter is often resulting in similar body part reductions in distant ostracod lineages (Gottwald, 1983). 


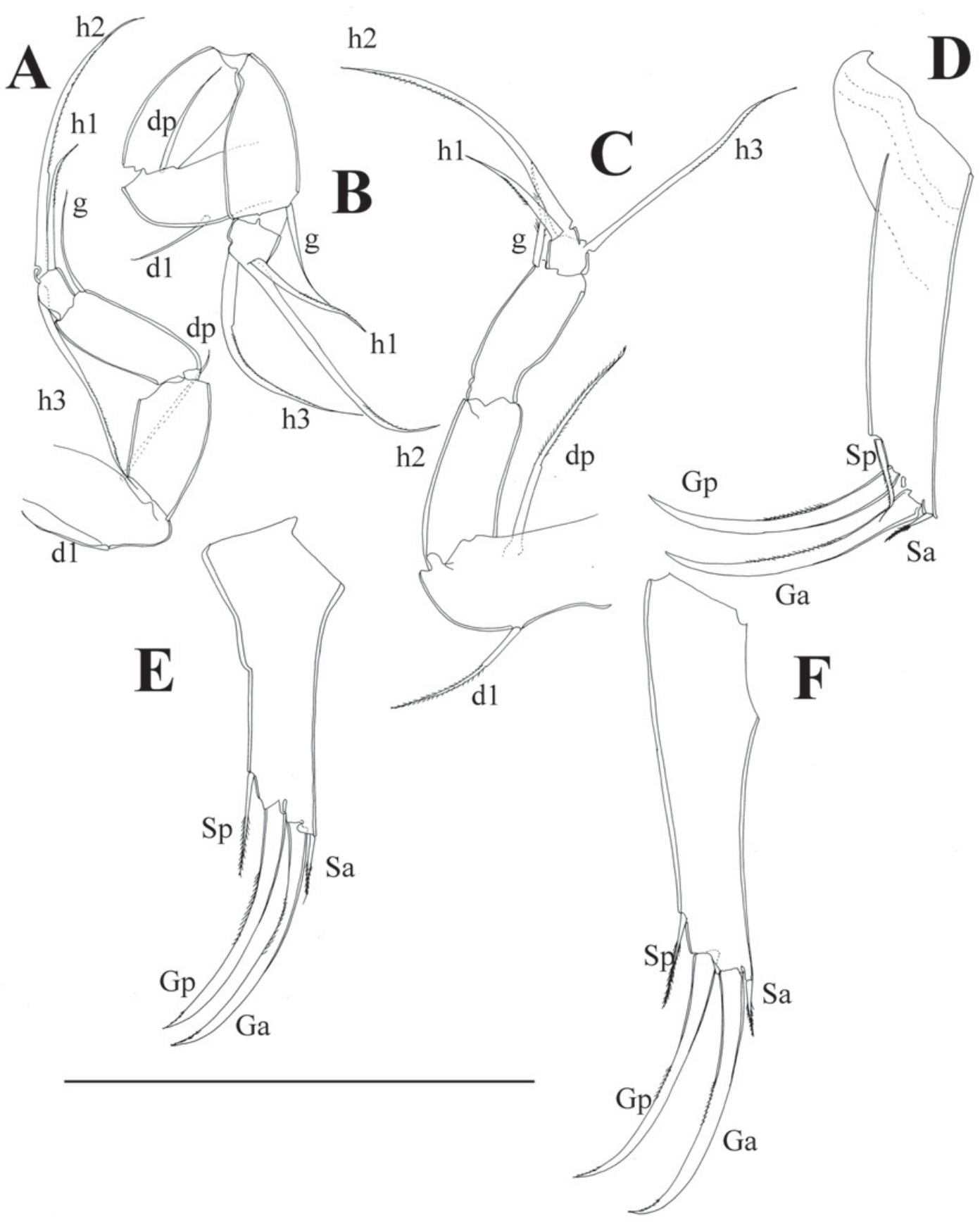

Fig. 7. Line drawings. A, B, E, F: N. schornikovi n. sp.; A, E: paratype female, Russia; B, F: holotype female, South Korea; C, D: N. danielopoli n. sp.; holotype female; A-C: L7; D-F: UR. Scale $=0.1 \mathrm{~mm}$.

Nannocandona is a Holarctic genus (Fig. 8) containing at the moment four named and potentially three new species, two of which have been found in interstitial waters in North America and one in the same type of ecosystem in the Vitosha Maountain in Bulgaria, at the moment under the name $N$. faba balcanica. Sywula (1967) only provides textual description of this subspecies, quoting small differences in the length of the various setae on the A1, L5 and UR, as well as longer sensory setae on the surface of the shell. On the other hand, Sywula (1967) mentioned no differences in the shell outline. In his later work (Sywula, 1974), the author provided drawings of soft parts of $N$. faba balcanica and microscopic photographs of its shell. The latter are indeed similar to the original description of $N$. faba and different from $N$. danielopoli. The soft parts are on the other hand peculiar, and indeed agree with the original description (Sywula, 1967) regarding the setae lengths. Additionally, terminal claws on the Md are conspicuous because both terminate in two strong setae, which also appear like chitinous extensions of the claws, but this can also be an artefact of slide preparation. A few years ago, one of us (I.K.) had a chance to observe a single female collected from the Beli Iskar River in Bulgaria (Vitosha Mountain) and this female had the 


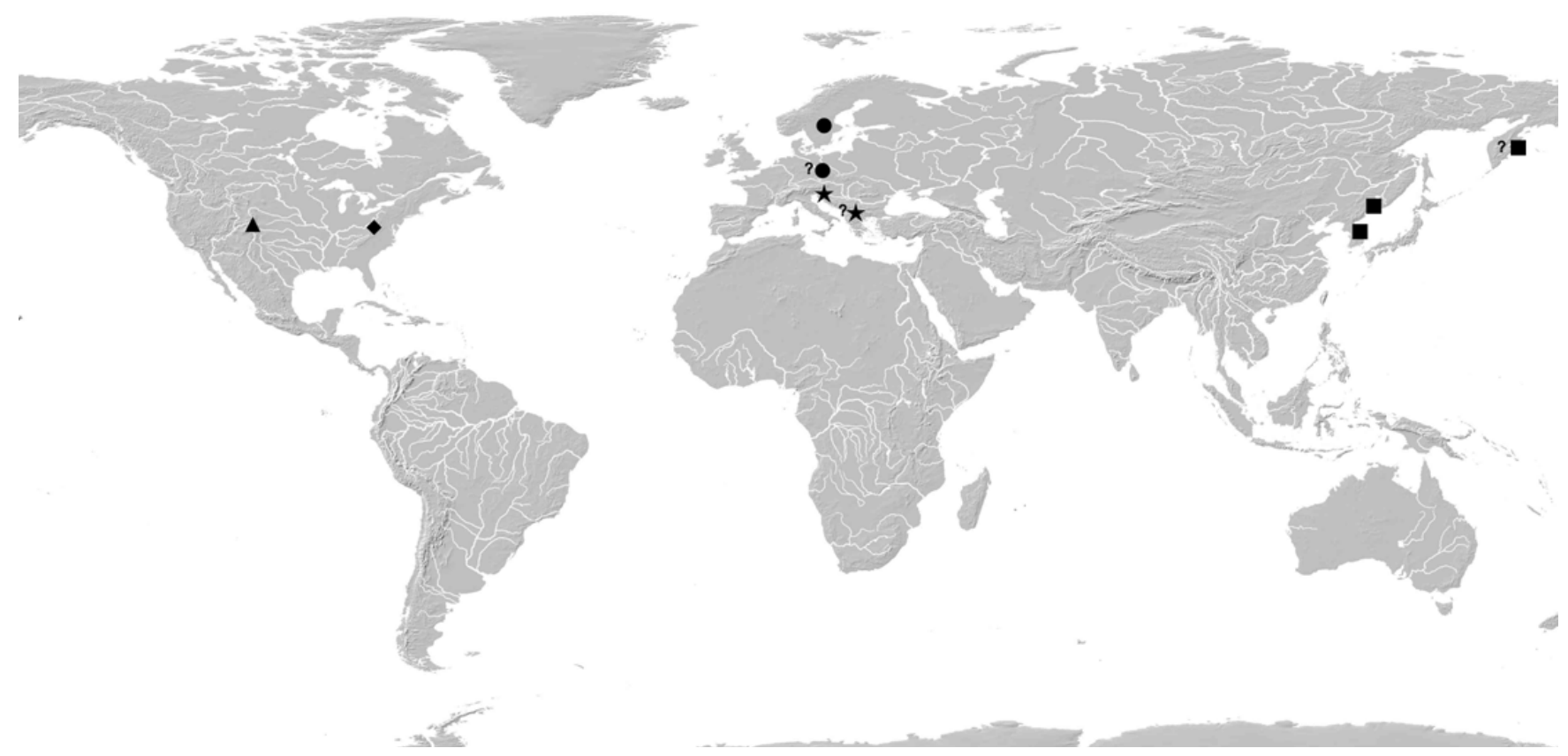

Fig. 8. Distribution of Nannocandona Ekman, 1914. Circle, N. faba; star, N. danielopoli n. sp.; square, N. schornikovi n. sp.; triangle, Nannocandona faba from Danielopol and Ward, 1990; diamond, Nannocandona sp. from Smith and Delorme (2009).

same soft parts like Sywula (1974) illustrated with the exception that the terminal claws on the Md looked like in both $N$. danielopoli and N. schornikovi. Unfortunately, the single female individual had a completely decalcified and deformed shell, preventing us to be more specific about our specimen and the ones Sywula $(1967,1974)$ studied. The map of distribution includes also a conspicuous record of $N$. faba and N. stygia from the interstitial waters near Sudety in Poland (black circle with a question mark on Fig. 8). Nannocandona stygia is a peculiar species, which stands apart from the other Nannocandona in not possessing two strong claws on the terminal segment of the Md palp. It is also considerably more elongated in lateral and narrower in dorsal view than other species, but has a common Nannocandona A1. In subsequent publication which lists all Polish subterranean species recorded until then, Sywula (1981) only included N. faba and did not mention $N$. stygia. In the revised diagnosis of the genus Nannocandona, proposed in the present publication, we did not exclude the peculiarly looking Md claws, because we believe that this is a very important character of the genus and that the character state as in N. stygia needs to be checked before drawing any further conclusions, especially because $N$. stygia is missing from the list of Polish subterranean species. The morphology of the terminal claws on the Md palp closely relates Nannocandona with the monospecific genus Paracandona Hartwig, 1899. Paracandona euplectella (Robertson, 1889) has been recorded throughout Holarctic as an inhabitant of small, swampy water bodies (see Meisch, 2000). Despite a strong resemblance in Md claws morphology, Nannocandona and Paracandona have a different L6, which is in the latter taxon 5-segmented, with a distinctly divided penultimate segment, and the seta " $\mathrm{f}$ " present. Unfortunately, $P$. euplectella was never illustrated or described in many details, probably because it has a distinctly looking surface of the shell (with polygonal pits and conspicuous reticulation) and cannot be confused with any of the known Holarctic Candoninae. Nevertheless, a study of other Paracandona soft parts may shed more light on the potential phylogenetic relationship between the two genera.

All Nannocandona species described so far reproduce asexually, and as Marmonier and Danielopol (1988) noted, reproductive females carry only one or two relatively large eggs, which seems to be common for subterranean ostracods in general (Danielopol, 1980; Marmonier et al., 1994; Tanaka, 2013). In comparison with other parthenogenetic ostracods, especially surface water ones that lay many more eggs (Rossi et al., 2011) or lineages that display a brooding care, such as darwinulids (see Pinto et al., 2007), the strategy of parthenogenetic subterranean Candoninae does not promise much success when it comes to the species dispersal strategies. The importance of resting eggs and parthenogenesis in freshwater ostracod evolutionary success has already been discussed elsewhere (Horne, 1993). The general conclusion is that, although important strategies, they were probably not the only causes of freshwater ostracods' current diversity and distribution (see Horne and Martens, 1998). Resting eggs have not been observed among Candoninae, although cases of torpidity were (Barclay, 1966; Delorme and Donald, 1969; Horne, 1993). Parthenogenesis is often encountered in ostracods, with cases of ancient asexual lineages, such as Darwinulidae (Schön et al., 2009), to the spatial and temporal parthenogenesis in many fresh- 
Table 2. Candoninae species with parthenogenetic distribution.

\begin{tabular}{|c|c|c|c|c|}
\hline Species name & Parthenogenesis & Rare males & General distribution & Habitat \\
\hline C. anceps & Yes? & No & Northern Europe & Lake \\
\hline C. aotearoa & Yes? & No & New Zealand & Surface water \\
\hline C. candida & No & Yes & Holarctic & Surface water \\
\hline Caa.iguassuensis & Yes & No & Brazil & Semiterrestrial \\
\hline Caa.schornikovi & Yes & No & Brazil & Semiterrestrial \\
\hline Cp. hummelincki & Yes & No & West Indies & Surface water \\
\hline Cr. angustissima & Yes? & No & Northern Europe & Springs \\
\hline Cr. brehmi & Yes & No & Japan & Interstitial waters, caves \\
\hline Cr. longipes & Yes? & No & Northern Europe & Wet moss \\
\hline Cr.pygmea & Yes? & No & Northern Europe & Wet moss \\
\hline Cr. reducta & No & Yes & Europe & Springs, deeper parts of lakes \\
\hline Cr. smithi* & Yes & No & South Korea & Interstitial waters \\
\hline Cr. vavrai & No & Yes & Europe & Surface water, interstitial \\
\hline F. angusta & Yes & No & Western Europe & Springs and interstitial \\
\hline F. breuli & Yes & Yes (Fossil) & Europe & Interstitial, caves, springs \\
\hline F. brevicornis & Yes & No & Western and Central Europe & Springs, interstitial \\
\hline F. caudata & No & Yes & Holarctic & Surface water, deeper parts of lakes \\
\hline F. groenlandica & Yes? & No & Greenland & Lake \\
\hline F. lapponica & Yes? & No & Northern Europe & Wet moss \\
\hline F. pennaki & Yes? & No & Colorado & Interstitial \\
\hline F. siliquosa & Yes & No & Britain & Surface water \\
\hline F. tyrolensis & Yes? & No & Western Europe & Interstitial \\
\hline F. wegelini & Yes & No & Holarctic & Interstitial, wells \\
\hline N. danielopoli & Yes & No & Central and Southern Europe & Interstitial \\
\hline N. faba & Yes & No & Holarctic & Interstitial \\
\hline N. schornikovi & Yes & No & Northeast Asia & Interstitial \\
\hline P. albicans & No & Yes? & Holarctic & Surface water \\
\hline P. caribbeana & Yes? & No & West Indies & Interstitial \\
\hline P. choi* $^{*}$ & Yes & No & South Korea & Interstitial \\
\hline P. jeanneli & Yes? & No & Kentucky & Caves \\
\hline P. marengoensis & Yes? & No & Kentucky & Caves \\
\hline P. pedropalensis & Yes? & No & Columbia & High altitude lake \\
\hline S. tea* & Yes & No & South Korea & Interstitial \\
\hline S. yakushimaensis & Yes? & No & Japan & Interstitial \\
\hline Tc. minuta & Yes & No & Madagascar & Semiterrestrial \\
\hline Tcp. wurdigae & Yes & No & Brazil & Semiterrestrial \\
\hline
\end{tabular}

Here we included only species which have been described on a large number of female individuals, or species with only females ever collected from several localities. Species described on females only but on very few specimens collected are not included.

C, Candona; Caa, Caaporacandona; Cp, Candonopsis; Cr, Cryptocandona; F, Fabaeformiscandona; N, Nannocandona;

P, Pseudocandona; S, Schellencanodna; Tc, Terrestricandona; Tcp, Terrestricypris.

*Although the species was described form a single locality and on a few specimens, it has been collected subsequently from many localities and always without males (Ivana Karanovic, unpublished data).

water Cyprididae (Horne and Martens, 1998). In few parthenogenetic species sexual and asexual lineages supposedly coexist in one population (see Bode et al., 2010). In comparison to both Cyprididae and Darwinulidae, Candoninae have only a handful of parthenogenetic species. The list in Table 2 does not include all species in which males have not been recorded, because the majority of those species have been described from a single or very few females and from a single locality, so it is very likely that males have not been collected only by chance. The list includes only species which have been described from a larger series and/or recorded several times. A majority of Candoninae parthenogenetic species (or species with rare bisexual reproduction) live in interstitial (or other subterranean) waters or some other extreme environments: semiterrestrial habitats, cold springs in Northern Europe, and the profundal zones of lakes. Incidents of parthenogenetic Candoninae living in surface open water bodies in temperate zones are very rare and some may also be due only to a chance finding of males (such as Candona aotearoa Chapman, 1963 in New Zealand). Cases of geographic parthenogenesis - where sexual reproduction is common in lower latitudes of a species distribution area, while parthenogenesis exists at higher latitudes (so common for many Holarctic Cyprididae; Horne and Martens, 1998) - are not recorded in Candoninae. There are only three Candoninae species with rare males (Table 2), but they are always geographically surrounded with strictly parthenogenetic populations.

Candoninae is the predominant ostracod group in subterranean waters around the world (Danielopol, 1978; Karanovic, 2007), with possibly long evolutionary history in these ecosystems. The latter has resulted in numerous genera living exclusively underground (see Karanovic, 
2007). All species belonging to stygobiont Candoninae lineages reproduce sexually. On the other hand, in genera with predominantly surface water species, such as Fabaeformiscandona Krstic, 1972 and Pseudocandona Kaufmann, 1900 (as defined by Namiotko et al., 2014), subterranean species tend to reproduce asexually. In contrary to Darwinulidae, Candoninae seem to be recent parthenogenetic spin-offs from sexual lineages. Horne and Martens (1999) argue that geographic parthenogenesis of the European ostracods (see above) is a result of extreme Holocene stability, in which asexual reproduction becomes advantageous due to the absence of twofold cost of sex. Fossil records of Nannocandona have all been identified as $N$. faba, with the earliest dating from Eemian interglacial stage, i.e., Late Pleistocene (Diebel and Pietrzeniuk, 1978), but none of the records mentions males. Sexual dimorphism in the shell shape among surface water Candoninae is strongly pronounced, but usually not so in subterranean species. The Nannocandona fossils are (almost) all associated with cold springs, which indicate that the species might have lived in surface waters. It is very likely that the species actively colonized subsurface waters before glaciations and populations may be isolated by the disappearance of surface water bodies and exposed to cold and stable temperatures. It is possible that all known Nannocandona species stem from a single widely distributed surface water species, but this species spread throughout the Holarctic not during the Quaternary but during the Neogene (Tertiary) via land bridges that connected Eurasia with North America. We don't know if parthenogenesis in Nannocandona is a result of colonization of environments with suboptimal conditions (Baltanás, 1998) or ecosystem stability (Horne and Martens, 1999). The fact is that the majority of Candoninae in all ecosystems reproduces sexually, which means that asexual lineages (such as Nannocandona) are recent spin-offs. Also the majority of subterranean Candoninae reproduces sexually, with asexuality only in those lineages with a minority of subterranean species. In order to better understand if there is any relation between parthenogenetic reproduction and life in the extreme environment in the Candoninae lineage, molecular, as well as broader biogeographic studies, should be applied in the future.

Acknowledgements. Financial support was provided by the National Institute of Biological Resources (NIBR) of Ministry of Environment, Korea (1834-302), Discovery of Korean Indigenous Species Project, NIBR (National Institute of Biological Resources). We would like to thank Dr. Erica Mejlon (Museum of Evolution, Uppsala University) for sending us type material.

\section{References}

Absolon A., 1973. Ostracoden aus einigen Profilen spätund postglazialer Karbonatablagerungen in Mitteleuropa. Mitt. Bayer. Staatssamml. Paläont. Hist. Geol., 13, 47-94.

Alm G., 1915. Monographie der Schwedischen SüsswasserOstracoden nebst systematischen Besprechungen der Tribus Podocopa. Zool. Bidr. Uppsala, 4, 1-248.
Baltanás A., 1998. Ostracod populations as metapopulations. In: Martens K. (ed.), Sex and Parthenogenesis - Evolutionary Ecology of Reproductive Modes in Non-Marine Ostracods, Backhuys Publ., Leiden, 229-241.

Barclay M.H., 1966. An ecological study of a temporary pond near Auckland, New Zealand. Aust. J. Marine Freshw. Res., 17, 239-258.

Bode S.N.S., Adolfsson S., Lamatsch D.K., Martins M.J.F., Schmit O., Vandekerkhove J., Mezquita F., Namiotko T., Rossetti G., Schön I., Butlin R.K. and Martens K., 2010. Exceptional cryptic diversity and multiple origins of parthenogenesis in a freshwater ostracod. Mol. Phylogenet. Evol., 54, 542-552.

Bou C., 1974. Recherches sur les eaux souterraines. Les méthodes de récolte dans les eaux souterraines interstitielles. Ann. Spéléol., 29, 611-619.

Bou C. and Rouch R., 1967. Un nouveau champ de recherches sur la faune aquatique souterraine. C. R. Acad. Sci., 265, 369-370.

Bretschko G., 1983. Die Biozönosen der Bettsedimente von Fliessgewässern - ein Beitrag der Limnologie zur naturnahen Gewässerregulierung, Bundesministerium für Land und Forstwetschaft, Wien, 161 p.

Broodbakker N.W. and Danielopol D.L., 1982. The chaetotaxy of Cypridacea (Crustacea, Ostracoda) limbs: proposals for a descriptive model. Bijdr. Dierk., 52, 103-120.

Chappuis P.A., 1942. Eine neue Methode zur Untersuchung der Grundwasserfauna, Vol. 6, Acta Scientifica MathematischNaturwissenschaftlichen Universität Francisco-Josephinae, Koloszvar, 107.

Danielopol D.L., 1978. Über die Herkunft und Morphologie der Süßwasser-hypogäischen Candoninae (Crustacea, Ostracoda). Sitzung. Österr. Akad. Wissensch., Mathem.Naturwissensch. Kl., Abt. I, 187, 1-162.

Danielopol D.L., 1980. Sur la Biologie de quelques Ostracodes Candoninae épigés et hypogés d'Europe. Bull. Mus. Nat. Hist. Nat., Paris, 2, 471-506.

Delorme L.D. and Donald D., 1969. Torpidity of freshwater ostracodes. Can. J. Zool., 47, 997-999.

Diebel K. and Pietrzeniuk E., 1975. Ostracoden aus dem holozänen Travertin von Bad Langensalza. Quartärpaläontologie, 1, 27-55.

Diebel K. and Pietrzeniuk E., 1977. Ostracoden aus dem Travertin von Taubach bei Weimar. Quartärpaläontologie, 2, 119-137.

Diebel K. and Pietrzeniuk E., 1984. Jungpleistozilne Ostracoden aus Sedimenten der Parkhôhlen von Weimar. Quartärpaläontologie, 5, 285-319.

Ekman S., 1914. Beitriige zur Kenntnis der Schwedischen Süsswasser-Ostracoden. Zool. Bidr. Uppsala, 3, 1-36.

Garm A., 2004. Revising the definition of the crustacean seta and setal classification systems based on examinations of the mouth part setae of seven species of decapods. Zool. J. Linn. Soc., 142, 233-252.

Gottwald J., 1983. Interstitielle Fauna von Galápagos XXX. Podocopida 1 (Ostracoda). Mikrof. Meeresb., 90, 1-187.

Higuti J. and Martens K., 2012. Description of a new genus and species of Candonopsini (Crustacea, Ostracoda, Candoninae) from the alluvial valley of the Upper Paraná River (Brazil, South America). Eur. J. Taxon., 33, 1-31.

Higuti J. and Martens K., 2014. Five new species of Candoninae (Crustacea, Ostracoda) from the alluvial valley of the 
Upper Paraná River (Brazil, South America). Eur. J. Tax., 106, 1-36.

Horne D.J. and Martens K., 1998. An assessment of the importance of resting eggs for the evolutionary success of Mesozoic non-marine cypridoidean Ostracoda (Crustacea). Arch. Hydrobiol. Spec. Issues Adv. Limnol., 52, 549-561.

Horne D.J. and Martens K., 1999. Geographical parthenogenesis in European non-marine ostracods: post-glacial invasion or Holocene stability? Hydrobiologia, 391, 1-7.

Horne F.R., 1993. Survival strategy to escape desiccation in a freshwater ostracod. Crustaceana, 65, 53-61.

Karanovic I., 2007. Candoninae (Ostracoda) from the Pilbara Region in Western Australia. Crustaceana Monogr. Ser., 7, $432 \mathrm{p}$.

Karanovic I., 2012. Recent Freshwater Ostracods of the World. Crustacea, Ostracoda, Podocopida, Springer, Heidelberg, $608 \mathrm{p}$.

Kempf E.K., 1980a. Index and bibliography of nonmarine Ostracoda. Index A. Sonderver. Geolog. Inst. Univ. Köln, 35, $1-188$.

Kempf E.K., 1980b. Index and bibliography of nonmarine Ostracoda. Index B. Sonderver. Geolog. Inst. Univ. Köln, 36, 1-180.

Kempf E.K., 1980c. Index and bibliography of nonmarine Ostracoda. Index C. Sonderver. Geolog. Inst. Univ. Köln, 37, $1-204$.

Kempf E.K., 1980d. Index and bibliography of nonmarine Ostracoda. Bibliography A. Sonderver. Geolog. Inst. Univ. Köln, 38, 1-186.

Kempf E.K., 1991. Index and bibliography of nonmarine Ostracoda. Bibliography B. Sonderver. Geolog. Inst. Univ. Köln, 77, 1-238.

Kempf E.K., 1997a. Index and bibliography of nonmarine Ostracoda. Index A, supplement. Sonderver. Geolog. Inst. Univ. Köln, 109, 1-142.

Kempf E.K., 1997b. Index and bibliography of nonmarine Ostracoda. Index B, supplement. Sonderver. Geolog. Inst. Univ. Köln, 110, 1-134.

Kempf E.K., 1997c. Index and bibliography of nonmarine Ostracoda. Index C, supplement. Sonderver. Geolog. Inst. Univ. Köln, 111, 1-152.

Kempf E.K., 1997d. Index and bibliography of nonmarine Ostracoda. Bibliography C. Sonderver. Geolog. Inst. Univ. Köln, 112, 1-144.

Krstic N., 1993. Several rare ostracode species of Bačka Quaternary. Proc. Geoinst. Belgrade, 28, 173-185.

Marmonier P. and Danielopol D.L., 1988. Découverte de Nannocandona faba Ekman (ostracoda, Candoninae) en base Autriche. Son origine et son adaptation au milieu interstitial. Vie Milieu, 38, 35-48.

Marmonier P. and Ward J., 1990. Superficial and interstitial Ostracoda of the South Platte River (Colorado, U. S. A.) - systematics and biogeography. Stygologia, 5, 225239.

Marmonier P., Bodergat A.M. and Doledec, S. 1994. Theoretical habitat templets, species traits, and species richness: ostracods (crustacea) in the Upper Rhône River and its floodplain. Freshw. Biol., 31, 341-355.

Martens K., 1992. On Namibcypris costata n. gen., n. sp. (Crustacea, Ostracoda, Candoninae) from a spring in northern Namibia, with the description of a new tribe and dicussion on the classification of the Podocopina. Stygologia, 7, 27-42.

Martens K., 1998. Sex and ostracods: a new synthesis. In: Martens K. (ed.), Sex and Parthenogenesis. Evolutionary Ecology of Reproductive Modes in Non-marine Ostracods, Backhuys Publisher, Leiden, 295-321.

Martens K. and Savatenalinton S., 2011. A subjective checklist of the recent, free-living, non-marine Ostracoda (Crustacea). Zootaxa Monogr., 2855, 1-79.

Martens K., Rossetti G. and Baltanás A., 1998. Reproductive modes and taxonomy. In: Martens K. (ed.), Sex and Parthenogenesis. Evolutionary Ecology of Reproductive Modes in Non-marine Ostracods. Backhuys Publisher, Leiden, 197-214.

Meisch C., 1996. Contribution to the taxonomy of Pseudocandona and four related genera, with the description of Schellencandona nov. gen., a list of the Candoninae genera, and a key to the European genera of the subfamily (Crustacea, Ostracoda). Bull. Soc. Natur. Luxemb., 97, 211-237.

Meisch C., 2000. Freshwater Ostracoda of Western and Central Europe. In: Schwoerbel, J. and Zwick, P. (eds.), Süßwasserfauna von Mitteleuropa, Spektrum Akademischer Verlag, Gustav Fischer, Heidelberg Berlin, 8/3, 1-522.

Meisch C., 2007. On the origin of the putative furca of the Ostracoda (Crustacea). Hydrobiologia, 585, 181-200.

Namiotko T., Danielopol D.L., Meisch C., Gross M. and Mori N., 2014. Redefinition of the genus Typhlocypris Vejdovský, 1882 (Ostracoda, Candonidae). Crustaceana, 87, 952-984.

Pinto R.L., Rocha E.E.F. and Martens K., 2005. On new terrestrial ostracods (Crustacea, Ostracoda) from Brazil, primarily from São Paulo State. Zool. J. Linn. Soc., 145, 145-173.

Pinto R.L., Rocha E.E.F. and Martens K., 2007. Early release of eggs and embryos in a brooding ancient asexual ostracod: brood selection or a gambling strategy to increase fecundity? Hydrobiologia, 585, 249-253.

Rossi V., Benassi G., Belletti F. and Menozzi P., 2011. Colonization, population dynamics, predatory behaviour and cannibalism in Heterocypris incongruens (Crustacea: Ostracoda). J. Limnol., 70, 102-108.

Schön I., Rossetti G. and Martens K., 2009. Darwinulid ostracods: ancient asexual scandals or scandalous gossip? In: Schön I., Martens K. and van Dijk P. (eds.), Lost Sex, Springer Science + Business, Heidelberg, 217-240.

Schornikov E.I., 2004. Class Ostracoda Latreille, 1802. In: Tyurin, A.N. and Drozdov, A.L. (eds.), Far-Eastern Marine Biospherical Reserve. Biota 2, Dalnauka, Vladivostok, 458-465 (in Russian with English summary).

Schornikov E.I., 2008. The ecological characteristic of the Rakovsky reservoir (Primorye Territory) on basis of the ostracod analysis. In: Makarchenko E.A. et al. (eds.), Vladimir Ya. Levanidov's Biennial Memorial Meetings, 4, Dalnauka, Vladivostok, 82-92 (in Russian with English summary).

Sidorov D.A. and Semenchenko K.A., 2012. New records of freshwater ostracods (Crustacea) from the Far East of Russia, with a checklist of recent freshwater ostracods of the region. Arthropod. Sel., 21, 227-234.

Smith A.J. and Delorme D.L., 2009. Chapter 19. Ostracoda. In: Thorp J.H. and Covich A. (eds.), Ecology and Classification 
of North American Freshwater Invertebrates, Elsevier, Amsterdam, 725-771.

Sywula T., 1967. Notes on Ostracoda. II. On some Bulgarian species. Bull. Soc. Amis Sci. Lett. Poznań, 8, 11-42.

Sywula T., 1974. Małzoraczki (Ostracoda). In: Jaczewskiego T. and Wolskiego T. (eds.), Fauna Słodkovodna Polski, 24, Państwowe Wydawnictwo Naukowe, Warszawa, 315 p.

Sywula T., 1976. New species of Ostracoda (Crustacea) from subteranean waters of Poland. Bull. Acad. Polon. Sci., 24, 271-278.
Sywula T., 1981. Małzoraczki (Ostracoda) wód podziemnych Polski. Roczn. Muz. Okręg. Częstoch., 2, 89-96.

Tanaka H., 2013. The mating behaviour of the seed shrimp Parapolycope spiralis (Ostracoda: Cladocopina), with insight into the evolution of mating systems in cryptic interstitial habitats. Biol. J. Linn. Soc., 109, 791-801.

Ward J.V. and Voelz N., 1994. Groundwater fauna of the South Platte river system, Colorado. In: Gibert J., Danielopol D.L. and Stanford J.A. (eds.), Groundwater Ecology, Academic Press, San Diego, 391-423. 